\title{
PRODUCTIVITY, FRUIT PHYSICOCHEMICAL QUALITY AND DISTINCTIVENESS OF PASSION FRUIT POPULATIONS ${ }^{1}$
}

\author{
NATAN RAMOS CAVALCANTE ${ }^{2}$, WILLIAN KRAUSE ${ }^{3}$, JOICE FERNANDES DE CARVALHO ${ }^{4}$, \\ MARIA KERHOLAYNE PEREIRA ROCHA ${ }^{4}$, EDNAMAR GABRIELA PALÚ ${ }^{5}$, \\ CELICE ALEXANDRE SILVA ${ }^{6}$
}

\begin{abstract}
The productivity and physicochemical quality evaluation is important, as it identifies superior populations. However, launching products requires following the descriptors according to DHE test instructions. Thus, this study aimed to evaluate three passion fruit populations with high productivity and physicochemical quality characteristics for commercial launch. The experiment was conducted at the State University of Mato Grosso experimental area, located in the municipality of Tangará da Serra, MT. The experimental design was complete randomized block design with four replicates and ten plants per plot. The physicochemical characteristics were submitted to analysis of variance and compared by the Tukey test. For the distinctiveness test, 25 descriptors were evaluated, where quantitative data have been converted into multicategoric data to obtain the dissimilarity matrix. From the dissimilarity matrix, groups were formed using the Tocher and UPGMA methods, Livestock and Supply Department. The highest productivity and number of fruits were verified for BRS Rubi Cerrado cultivar and UNEMAT S10 population. Populations and cultivars presented physicochemical characteristics that meet the required quality for both fresh consumption and industry use. Based on the distinction test among genotype, it was observed that the descriptors were effective for population differentiation. UNEMAT S10 population has characteristics that distinguish it from other cultivars and populations evaluated, and presents high agronomic performance; therefore, it can be launched as a commercial cultivar.
\end{abstract}

Index terms: Commercial launch, Descriptors, Passiflora edulis Sims.

\section{PRODUTIVIDADE, QUALIDADE FÍSICO-QUÍMICA DE FRUTOS E DISTINGUIBILIDADE DE POPULAÇÕES DE MARACUJAZEIRO-AZEDO}

RESUMO - A avaliação da produtividade e da qualidade físico-química apresenta importância, pois permite identificar populações superiores. Porém, para lançar material, é necessário seguir os descritores conforme as instruções para a execução dos ensaios de DHE. Desta maneira, objetivou-se avaliar três populações de maracujazeiro-azedo que apresentem características de alta produtividade e qualidade físico-química, para lançamento comercial. O experimento foi conduzido na área experimental da Universidade do Estado de Mato Grosso, situada no município de Tangará da Serra-MT. O delineamento experimental foi o de blocos completos casualizados, com quatro repetições e dez plantas por parcela. As características físico-químicas foram submetidas à análise de variância e comparadas pelo teste de Tukey. Para avaliar a distinguibilidade, foram utilizados 25 descritores, onde os dados quantitativos foram convertidos em multicategóricos, visando a obter matriz de dissimilaridade. A partir da matriz de dissimilaridade, formaram-se grupos pelo método de Tocher e UPGMA. A maior produtividade e o maior número de frutos foram verificados na cultivar BRS Rubi do Cerrado e na população UNEMAT S10. As populações e as cultivares apresentaram características físico-químicas que atendem as qualidades exigidas tanto para o mercado in natura como para a indústria. Com base no ensaio de distinção entre genótipos, observou-se que os descritores foram eficientes para a diferenciação das populações. A população UNEMAT S10 possui características que a distinguem das demais cultivares e populações avaliadas, além de possuir alto desempenho agronômico e, portanto, de poder ser lançada como cultivar comercial.

Termos para indexação: Lançamento comercial, descritores, Passiflora edulis Sims.

'(Paper 150-15). Received May 29, 2015. Accepted June 06, 2016.

${ }^{2} \mathrm{MSc}$ in Genetics and Plant Breeding at the State University of Mato Grosso - UNEMAT. Tangará da Serra - MT. Email: natancavalcante2@hotmail.com

${ }^{3} \mathrm{PhD}$ at the Graduate Program in Genetics and Plant Breeding, State University of Mato Grosso - UNEMAT. Tangará da Serra - MT. Email: krause@unemat.br

${ }^{4}$ Undergraduate students in agronomy, State University of Mato Grosso - UNEMAT. Tangará da Serra - MT. Emails: joicecarvalho_3@ hotmail.com; kerholaynerocha@hotmail.com

${ }^{5} \mathrm{PhD}$ and Laboratory Technician by the State University of Mato Grosso - UNEMAT. Tangará da Serra - MT. Email: gabrielapalu@unemat.br ${ }^{6} \mathrm{PhD}$ at the Graduate Program in Genetics and Plant Breeding, State University of Mato Grosso - UNEMAT. Tangará da Serra - MT. Email: celice@unemat.br 


\section{INTRODUCTION}

Brazil is the world's largest producer of passion fruit, accounting for approximately $60 \%$ of total world production. However, the average passion fruit productivity in Brazil is low, with values close to 14.49 tons ha $^{-1}$ year $^{-1}$ (IBGE, 2014), due to the low availability and use of improved cultivars (GONÇALVES Et al., 2007).

Although Brazilian production is quite significant in relation to that of other passion fruit producing countries, the volume produced is insufficient to meet domestic market demand due to the increase in fresh fruit consumption and juice processing. Thus, increasing passion fruit production is essential for the Brazilian agriculture (PIMENTEL et al., 2009).

The genetic improvement of passion fruit in Brazil is directly related to productivity and fruit quality. A quality fruit is one that meets expectations of the different consumer segments in its internal and external characteristics. Internal characteristics are related to flavor (sugar content and acidity) and juice content (yield), while external characteristics such as appearance, which is associated with fruit standardization, are critical in the choice by the consumer (BALBINO, 2005).

One of the greatest challenges of passion fruit research is related to genetic improvement. The number of commercial passion fruit cultivars is small, considering the great variability of agroecosystems in Brazil. Commercial passion fruit cultivars available in Brazil are the 270 series intravarietal hybrids developed by the Agronomic Institute of Campinas, the hybrids developed by the Brazilian Agricultural Research Company - Embrapa Cerrados, and the Flora Brasil series cultivars (MELETTI, 2011). However, among passion fruit cultivars available in the market, none of them was developed for cultivation in the State of Mato Grosso.

However, in order to develop a commercial cultivar, there are several standards that it must be in line with. Thus, in April 1997, the law No. 9,456 that protects cultivars was established, where to acquire the protection of a cultivar, it must be distinguished from the genitor from which it was originated and from the other cultivars in the market. In addition, it must present some degree of difference, and these differences must be maintained in the next generations (MAPA, 2008).

The aim of this study was to evaluate the agronomic performance and the physicochemical characteristics of passion fruit, as well as the distinction among populations from the genetic improvement program held at the State University of Mato Grosso.

\section{MATERIAL AND METHODS}

The experiment was implemented in December 2012 in the experimental area of the State University of Mato Grosso in the municipality of Tangará da Serra-MT (14³7'10 '’S, 57²9'09 "W and $321 \mathrm{~m}$ asl). The local climate is tropical, presenting well defined seasons, a dry season from May to September and a rainy season from October to April. The average annual rainfall ranges from 1300 to $2000 \mathrm{~mm}$, with annual temperatures ranging from 16 to $36^{\circ} \mathrm{C}$ (Martins et al., 2010).

The soil is classified as a Dystroferric Red Latosol, with clay content above $40 \%$, clayey texture and flat to slightly wavy relief (EMBRAPA, 2006). The results of the soil analysis performed at $0-20 \mathrm{~cm}$ depth showed the following values: $\mathrm{pH}\left(\mathrm{CaCl}_{2}\right)=4.4$; $\mathrm{H}+\mathrm{Al}=54 \mathrm{mmol} \mathrm{dm}^{-3} ; \mathrm{P}($ resin $)=1 \mathrm{mg} \mathrm{dm}^{-3} ; \mathrm{K}=0.3$ $\mathrm{mmol}_{\mathrm{c}} \mathrm{dm}^{-3} ; \mathrm{Ca}^{2+}=2 \mathrm{mmol}_{\mathrm{c}} \mathrm{dm}^{-3} ; \mathrm{Mg}^{2+}=1 \mathrm{mmol}_{\mathrm{c}}$ $\mathrm{dm}^{-3}$; base saturation, $6 \%$. Liming and planting and cover fertilization were performed according to the soil analysis, according to recommendations of Borges et al. (2006).

Seven treatments were evaluated, four commercial cultivars (BRS Sol do Cerrado, BRS Gigante Amarelo, BRS Rubi do Cerrado and FB 200) and three populations from the UNEMAT passion fruit breeding program called UNEMAT S10, UNEMAT S5 and UNEMAT C5. UNEMAT S10 genotype was obtained from the selection of six plants from BRS Gigante Amarelo x BRS Rubi do Cerrado crossing, two plants from FB100 x BRS Rubi do Cerrado crossing, one plant from FB200 x BRS Rubi do Cerrado crossing and one plant from BRS Sol of the cerrado x BRS Rubi do Cerrado crossing. After selection, plants were recombined using half-sib progenies, where the mother was the plant selected and the father was the mixture of pollen from all selected plants.

UNEMAT S5 genotype was obtained from the selection of four plants from BRS Gigante Amarelo $x$ BRS Rubi do Cerrado crossing and one plant from FB100 x BRS Rubi do Cerrado crossing. The selected plants were recombined using half-sib progenies, where the mother was the plant selected and the father was the mixture of pollen from all selected plants. UNEMAT S10 and UNEMAT S5 genotypes are open pollination varieties. For the formation of the UNEMAT C5 genotype, the same plants selected in the UNEMAT S5 genotype were 
used. However, these plants were cloned and mixed to form a clonal variety.

The experimental design was a randomized block design, with four replicates and ten plants per plot. The spacing used was $3.0 \mathrm{~m}$ between plants and $3.0 \mathrm{~m}$ between rows in order to allow the mobilization of machines within the experiment. The plant conduction system was vertical cordon, with $2.5 \mathrm{~m}$ stakes spaced $6.0 \mathrm{~m}$ and with \# 12 smooth wire from $2.0 \mathrm{~m}$ of the ground. Cultural treatments such as irrigation, fertilization, pruning, and pest and disease control were recommended for passion fruit cultivation (BRUCKNER and PICANÇO, 2001). When necessary, plants were irrigated using the micro sprinkler system, applying supplementary water during drought periods.

In order to evaluate the agronomic performance and fruit quality, the following characteristics were analyzed: fruit mass, which was obtained by direct weighing of ten fruits using Marte brand digital scale (model MS $30 \mathrm{k} 1$ ) and the arithmetic mean of the total weight of fruits by the total number of fruits was later performed. Pulp percentage (PP) was obtained by weighing the pulp (seeds with aryl), dividing by the total weight of fruits and multiplied by 100 .

Fruit length and fruit diameter were obtained from measurements of the arithmetic mean of the longitudinal dimensions and the transversal dimensions of fruits using a digital caliper. Peel thickness was determined using a digital caliper by means of the arithmetic mean of the measures of four peel points in the median portion of fruits transversely cut in the direction of the largest diameter. The number of fruits per hectare represents the number of fruits collected during the conduction of the experiment and productivity was evidenced by the sum of the total of harvests performed during the conduction of the experiment.

Total soluble solids were determined through refractometry using a digital bench refractometer (model RTD-45), with reading in the $0-45^{\circ}$ Brix range. Readings were performed by placing drops of juice from the three samples, and then the arithmetic mean of samples was determined to obtain a representative final value of samples.

$\mathrm{pH}$ was determined by immersion of the $\mathrm{pH}$ meter sensor (potentiometer with glass electrode), digital model (MA-PA200) in the juice extracted from fruits. To calculate the total titratable acidity, which is expressed as a percentage of citric acid, the methodology recommended by AOAC (1990) was used, by diluting $5 \mathrm{ml}$ of juice composed of the minimum sample of three fruits in distilled water in the proportion of $25 \mathrm{~mL}$ using as indicator 5 drops of phenolphthalein at $1 \mathrm{~g} \mathrm{~L}^{-1}$. With the aid of a digital burette (Diditrate Pro $50 \mathrm{ml}$ - Jencons), each sample was titrated with $0.1 \mathrm{~mol} \mathrm{~L}-1 \mathrm{NaOH}$ under constant stirring. The results were expressed in grams of citric acid per $100 \mathrm{ml}$ of juice using the following formula:

$$
\mathrm{G}=\frac{\text { V.f.N.PE } .100}{\mathrm{P}}
$$

where:

$\mathrm{G}=$ citric acid equivalent per $100 \mathrm{ml}$ of juice; $\mathrm{V}=$ volume of $\mathrm{NaOH} 0.1 \mathrm{~mol} \mathrm{~L}^{-1}$ used in the titration (L); $\mathrm{F}=$ correction factor $(0.94) ; \mathrm{N}=\mathrm{NaOH}$ normality $\left(\mathrm{eq} \mathrm{L}^{-1}\right)$ of $0.1 ; \mathrm{PE}=$ citric acid equivalent weight $\left(\mathrm{g} \mathrm{eq}^{-1}\right)$ of $64 ; \mathrm{P}=$ juice volume $(\mathrm{mL})$.

The ratio determination was made by dividing the total soluble solids value by the titratable total acid value. To evaluate the distinctiveness, 25 morphological characteristics according to instructions from the Ministry of Agriculture, Livestock and Food Supply were used (MAPA, 2008).

For the dissimilarity analysis using all the characteristics, quantitative data were converted into qualitative data (multicategoric), aiming to obtain a single dissimilarity matrix that allows estimating the similarity considering a set of multicategoric variables by means of simple index of coincidence (CRUZ, 2008).

$$
\mathrm{s}_{\mathrm{ii}}=\frac{\mathrm{C}}{\mathrm{C}+\mathrm{D}}
$$

where:

C: total category concordance for all variables considered;

D: total category discordance for all variables considered.

From the dissimilarity matrix, groups were formed by the Tocher optimization method. The dissimilarity matrix was also used for the grouping of accesses using the UPGMA hierarchical method (Unweighted Pair Group Mean Average) using the Genes software (CRUZ, 2013).

The physicochemical characteristics were submitted to analysis of variance and the means were compared by the Tukey test at $5 \%$ error probability. The Sisvar software was used for statistical analyses (FERREIRA, 2011). 


\section{RESULTS AND DISCUSSION}

There was significant difference $(\mathrm{P} \leq 0.01)$ for characteristics number of fruits, yield, fruit mass, length and fruit diameter. However, no significant difference for pulp percentage and peel thickness was observed (Table 1).

UNEMAT C5 (135.286 un ha-1) and UNEMAT C5 populations (104.237un ha-1), as well as BRS Rubi do Cerrado commercial cultivar (133.786 un ha-1) showed the highest number of fruits; however, for UNEMAT C5 population, it did not reflect productivity, and BRS Rubi do Cerrado and UNEMAT S10 were the most productive $(27,509$ and $25,958 \mathrm{~kg} \mathrm{ha}^{-1}$, respectively) (Table 2). It is noteworthy that the difference in productivity and number of fruits of UNEMAT S10 genotype and UNEMAT S5 and UNEMAT C5 genotypes may be due to problems with self-incompatibility as a result of the smaller amount of plants that were selected and recombined for the formation of the last two populations.

When evaluating the productivity of seven passion fruit cultivars (IAC 275, IAC 277, FB 100, FB 200, BRS Sol do Cerrado, BRS Gigante Amarelo and BRS Ouro Vermelho) in the region of Tangará da Serra, Krause et al. (2005) reported that FB 100 $\left(18,469 \mathrm{~kg} \mathrm{ha}^{-1}\right)$, FB $200\left(19,908 \mathrm{~kg} \mathrm{ha}^{-1}\right)$ and BRS Ouro Vermelho $\left(17,165 \mathrm{~kg} \mathrm{ha}^{-1}\right)$ cultivars were the most productive. However, when compared to the UNEMAT S10 population, all these cultivars showed lower productivity, evidencing the potential of this population for the edaphoclimatic conditions of the region.

BRS Gigante Amarelo cultivar presented the highest average for fruit mass characteristics ( $256.91 \mathrm{~g})$, being $28.8 \%$ higher when compared to FB 200 cultivar, which showed the lowest fruit mass (Table 2). Zaccheo et al. (2012) evaluated fruit mass in passion fruit hybrids and observed values lower than those of the present study, which ranged from 199 to $205 \mathrm{~g}$.

For fruit length characteristics, BRS Gigante Amarelo cultivar showed the highest value. As for fruit diameter characteristics, BRS Gigante Amarelo, UNEMAT C5, BRS Sol do Cerrado and UNEMAT S10 cultivar stood out. However, according to the Brazilian program for the improvement of commercial fruit standards and vegetable packaging (BRASIL, 2011), classes are determined using a numerical scale (1-5), by measuring fruit diameter. It was observed that all cultivars and populations studied were in class 4 ( $\geq 75$ to $<85 \mathrm{~mm}$ ), which is considered an optimal classification standard.
For peel thickness characteristic, cultivars and populations maintained a similar response, presenting values ranging from $7.54 \mathrm{~mm}$ to $8.87 \mathrm{~mm}$. For Cavichioli et al. (2008), passion fruits with finer peel present higher amounts of pulp. Thus, the genetic improvement of interest should point that the increase in fruit size is inversely proportional to peel thickness (MEDEIROS et al., 2009). For table fruits, it is interesting that the bark is thicker to avoid post harvest damage caused by transportation.

Although BRS Gigante Amarelo cultivar has larger fruits, it did not reflect in pulp percentage, where cultivars and populations did not differ significantly (Table 2). Except for the UNEMAT C5 population, the pulp percentage obtained was higher than the standards recommended for industry, which should be at least 33\% (NASCIMENTO, 1999). Likewise, Negreiros et al. (2008) and Greco et al. (2014) obtained maximum values of 45.8 and $38.6 \%$, respectively, in the evaluation of different passion fruit genotypes in the regions of Humaitá (AC) and Vargem Bonita (DF), respectively.

For the chemical characteristics, there was a significant difference for hydrogen ion potential $(\mathrm{P} \leq 0.01)$ and for ratio $(\mathrm{P} \leq 0.05)$. However, for total soluble solids and total titratable acidity, no significant difference was observed (Table 3).

Although there is no difference between cultivars and populations evaluated for total soluble solids, the values are within the range from 11.56 to $12.43^{\circ}$ Brix (Table 4). The processing industries require that fruits have high sugar content, and the higher the content of total soluble solids, the lower the amount of raw material to obtain the final product; thus fruits with higher content of soluble solids will have higher acceptance by processing industries (NASCIMENTO et al., 1999). Thus, the higher the TSS value, the lower the amount of fruit used to obtain a certain amount of concentrated juice, increasing the industry efficiency and reducing production costs.

UNEMAT S10 (3.37) and UNEMAT C5 populations (3.36) and FB 200 cultivar (3.35) showed the highest hydrogen ion potential values, significantly differing only from BRS Gigante Amarelo cultivar $(3,22)$, but all treatments presented acidic fruits, with $\mathrm{pH}$ values ranging from 3.22 to 3.37 , maintaining value within the limits established by the Brazilian legislation that establishes range from 2.7 to 3.8 (Table 4). Medeiros et al. (2009) reported that $\mathrm{pH}$ values up to 4.2 do not compromise the industrialization process but allow flexibility in the addition of sugars that varies according to the peculiar characteristics of each consumer market. 
The mean total titratable acidity values did not differ between cultivars and populations. Values ranged from 3.12 to 3.74 . For industrial processing purposes, acidity should be between 3.2 and $4.5 \%$, which allows less addition of acidification agents (FOLEGATTI and MATSUURA, 2002). Unlike the result found in the present study, Farias et al. (2007) found average titratable acidity values of $5.2 \%$ in the region of Rio Branco-AC

Typically, the higher the ratio value, the more palatable the fruit juice or pulp is, since the content of total soluble solids is high and / or the acidity is low. In the present study, the ratio value ranged from 3.15 to 3.99 , with mean value of 3.62 (Table 4), with the highest values for BRS Rubi do Cerrado (3.99), UNEMAT S5 (3.94), FB 200 (3.76), UNEMAT S10 (3.66), UNEMAT C5 (3.53) and BRS Sol do Cerrado (3.37) when compared to BRS Gigante Amarelo cultivar (3.15), which presented lower value. Zaccheo et al. (2012) found ratio values in passion fruit hybrids close to those of the present study, ranging from 4.3 to 2.6. Abreu et al. (2009) found for BRS Gigante Amarelo cultivar, ratio value of 1.92. In general, it was observed that populations and cultivars presented physicochemical characteristics that meet the quality demanded by both fresh market and industry.

In order to evaluate the distinctiveness of populations from the intrapopulational breeding program of passion fruit with commercial cultivars, 25 morphological characteristics were used, according to instructions of the national crop protection service of the Ministry of Agriculture, Livestock and Supply (MAPA, 2008).

From the results obtained, the Tocher method was applied, which detected the formation of three distinct groups (Table 5). The first group consisted of UNEMAT S10, UNEMAT C5, UNEMAT S5 populations and FB 200 cultivars. The second group consisted of BRS Sol do Cerrado and BRS Rubi do Cerrado cultivars. The third group was composed only of BRS Gigante Amarelo cultivar.

In Figure 1, the UPGMA hierarchical clustering method formed the same groups as the Tocher method, demonstrating the consistency in analyses. Sousa et al. (2012) evaluated the genetic divergence of $P$. edulis and $P$. cincinnata accesses based on physical and chemical characteristics of fruits and also observed consistency in the cluster analysis of accesses by the Tocher method and the UPGMA hierarchical method.

Of the 25 descriptors used, 15 contributed to distinctiveness. UNEMAT S10 population showed distinctiveness from the other cultivars and populations evaluated and high agronomic performance, being able to be launched as commercial cultivar. To characterize $P$. edulis genotypes, Castro et al. (2012) selected minimum morphological descriptors to differentiate passion fruit varieties. This result was obtained through principal components analysis, which indicated 22 of the 28 descriptors analyzed for the characterization of P. edulis with high contribution in the total variation.

TABLE 1- Analysis of variance for physical characteristics of passion fruit genotypes (four cultivars and three populations). Tangará da Serra-MT, 2015.

\begin{tabular}{lcccccccc}
\hline \multirow{2}{*}{$\begin{array}{c}\text { Sources } \\
\text { of variation }\end{array}$} & \multirow{2}{*}{ DF } & \multicolumn{9}{c}{ Mean squares } \\
\cline { 2 - 9 } Block & 3 & 307397779 & 16485188 & 190.8 & 1.8 & 7.7 & 4.8 & 0.2 \\
Genotypes & 6 & $39984283^{* *}$ & $131296041^{* *}$ & $2484.4^{* *}$ & $26.4^{\text {ns }}$ & $89.9^{* *}$ & $39.3^{* *}$ & $0.9^{\text {ns }}$ \\
Error & 18 & 279460270 & 9302297 & 405.0 & 13.7 & 12.3 & 6.6 & 0.7 \\
\hline Total & 27 & - & - & - & - & - & - & - \\
\hline Mean & - & 96544 & 19252 & 201.9 & 37.1 & 89.7 & 78.1 & 7.9 \\
VC $(\%)$ & - & 17.3 & 15.8 & 9.9 & 9.9 & 3.9 & 3.3 & 10.6 \\
\hline
\end{tabular}

NF - number of fruits (units), PROD - productivity $\left(\mathrm{kg} \mathrm{ha}^{-1}\right), \mathrm{MF}$ - fruit mass (g), PP - pulp percentage (\%), CF - fruit length, DF - fruit diameter $(\mathrm{mm}), \mathrm{EC}$ - peel thickness $(\mathrm{mm})$. Not significant. ** and * Significant at 1 and $5 \%$ probability, by the $\mathrm{F}$ test, respectively. 
TABLE 2- Mean of number of fruits (NF), productivity (PROD), fruit mass (MF), fruit length (CF), fruit diameter (DF), peel thickness (EC), pulp percentage (PP) in four passion fruit cultivars and three populations. Tangará da Serra-MT, 2015.

\begin{tabular}{|c|c|c|c|c|c|c|c|}
\hline Cultivars and populations & $\begin{array}{l}\text { NF } \\
\text { (un) }\end{array}$ & $\begin{array}{c}\text { PROD } \\
\left(\mathrm{kg} \mathrm{ha}^{-1}\right)\end{array}$ & $\begin{array}{l}\text { MF } \\
(\mathrm{g})\end{array}$ & $\begin{array}{l}\mathrm{CF} \\
----\end{array}$ & $\begin{array}{c}\mathrm{DF} \\
-(\mathrm{mm})\end{array}$ & EC & $\begin{array}{l}\text { PP } \\
(\%)\end{array}$ \\
\hline BRS Sol do Cerrado & $80.071 .3 \mathrm{~cd}$ & $15.759 .7 \mathrm{~cd}$ & $196.2 b$ & $88.3 b$ & $78.3 \mathrm{ab}$ & $7.81 \mathrm{a}$ & $38.6 \mathrm{a}$ \\
\hline BRS Gigante Amarelo & $46.499 .9 \mathrm{~d}$ & $11.664 .3 \mathrm{~d}$ & $256.9 \mathrm{a}$ & $99.6 \mathrm{a}$ & $84.2 \mathrm{a}$ & $7.54 \mathrm{a}$ & $35.1 \mathrm{a}$ \\
\hline BRS Rubi do Cerrado & $133.785 .5 \mathrm{ab}$ & $27.509 .7 \mathrm{a}$ & $195.0 \mathrm{~b}$ & $90.3 b$ & $75.9 \mathrm{~b}$ & $7.81 \mathrm{a}$ & $38.8 \mathrm{a}$ \\
\hline FB 200 & $79.976 .1 \mathrm{~cd}$ & $15.768 .9 \mathrm{~cd}$ & $182.7 \mathrm{~b}$ & $88.4 \mathrm{~b}$ & $75.0 \mathrm{~b}$ & $7.60 \mathrm{a}$ & $40.2 \mathrm{a}$ \\
\hline UNEMAT S5 & $95.952 .2 \mathrm{bc}$ & $18.104 .1 \mathrm{~cd}$ & $186.9 \mathrm{~b}$ & $84.1 \mathrm{~b}$ & $75.7 \mathrm{~b}$ & $8.33 \mathrm{a}$ & $36.2 \mathrm{a}$ \\
\hline UNEMAT S10 & $135.285 .5 \mathrm{a}$ & $25.958 .1 \mathrm{ab}$ & $198.5 b$ & $88.6 b$ & $78.2 \mathrm{ab}$ & $7.79 \mathrm{a}$ & $38.1 \mathrm{a}$ \\
\hline UNEMAT C5 & 104.237.9abc & $20.003 .1 b c$ & $197.5 b$ & $88.6 b$ & $79.3 \mathrm{ab}$ & $8.87 \mathrm{a}$ & $32.7 \mathrm{a}$ \\
\hline
\end{tabular}

Means followed by equal letters do not differ by the Tukey test at $5 \%$ probability.

TABLE 3- Analysis of variance for the chemical characteristics of passion fruit genotypes (four cultivars and three populations). Tangará da Serra-MT, 2015.

\begin{tabular}{lccccc}
\hline \multirow{2}{*}{ Source of Variation } & \multirow{2}{*}{$\mathrm{DF}$} & \multicolumn{5}{c}{ Mean squares } \\
\cline { 3 - 6 } & & $\mathrm{TSS}$ & $\mathrm{pH}$ & $\mathrm{ATT}$ & RAT \\
\hline Block & 3 & 1,9 & 0,004 & 0,4 & 0,08 \\
Genotypes & 6 & $0,4^{\text {ns }}$ & $0,01^{* *}$ & $0,2^{\text {ns }}$ & $0,3^{*}$ \\
Error & 18 & 0,9 & 0,002 & 0,09 & 0,1 \\
\hline Total & 27 & - & - & - & - \\
\hline Mean & - & 11,9 & 3,3 & 3,3 & 3,6 \\
VC $(\%)$ & - & 8,2 & 1,5 & 9,3 & 9,6 \\
\hline
\end{tabular}

TSS - total soluble solids $\left({ }^{\circ}\right.$ Brix $), \mathrm{pH}$ - hydrogen ion potential, TTA - total titratable acidity (\%), RAT - ratio. Ns Not significant. ** and * Significant at 1 and $5 \%$ probability by the $\mathrm{F}$ test, respectively.

TABLE 4-Total Soluble Solids (TSS), hydrogen ion potential (pH), total titratable acidity (TTA), (TSS / TTA) ratio in four passion fruit cultivars and three populations. Tangará da Serra-MT, 2015.

\begin{tabular}{lcccc}
\hline \multicolumn{1}{c}{ Cultivars and populations } & TSS $\left({ }^{\circ}\right.$ Brix $)$ & $\mathrm{pH}$ & TTA & TSS / TTA \\
\hline BRS Sol do Cerrado & $12.43 \mathrm{a}$ & $3.26 \mathrm{ab}$ & $3.74 \mathrm{a}$ & $3.37 \mathrm{ab}$ \\
BRS Gigante Amarelo & $11.63 \mathrm{a}$ & $3.22 \mathrm{~b}$ & $3.69 \mathrm{a}$ & $3.15 \mathrm{~b}$ \\
BRS Rubi do Cerrado & $12.29 \mathrm{a}$ & $3.31 \mathrm{ab}$ & $3.17 \mathrm{a}$ & $3.99 \mathrm{a}$ \\
FB 200 & $11.56 \mathrm{a}$ & $3.35 \mathrm{a}$ & $3.16 \mathrm{a}$ & $3.76 \mathrm{ab}$ \\
UNEMAT S5 & $12.08 \mathrm{a}$ & $3.29 \mathrm{ab}$ & $3.12 \mathrm{a}$ & $3.94 \mathrm{ab}$ \\
UNEMAT S10 & $11.87 \mathrm{a}$ & $3.37 \mathrm{a}$ & $3.25 \mathrm{a}$ & $3.66 \mathrm{ab}$ \\
UNEMAT C5 & $11.77 \mathrm{a}$ & $3.36 \mathrm{a}$ & $3.40 \mathrm{a}$ & $3.53 \mathrm{ab}$ \\
\hline
\end{tabular}

Means followed by equal letters do not differ by the Tukey test at $5 \%$ probability. 
TABLE 5- Groups established by the Tocher method based on multicategoric characters. Tangará da SerraMT, 2015.

\begin{tabular}{cc}
\hline Groups & Cultivar and populations \\
\hline I & UNEMAT S10, UNEMAT C5, FB 200 and UNEMAT S5 \\
II & BRS Sol do Cerrado and BRS Rubi do Cerrado \\
III & BRS Gigante Amarelo \\
\hline
\end{tabular}

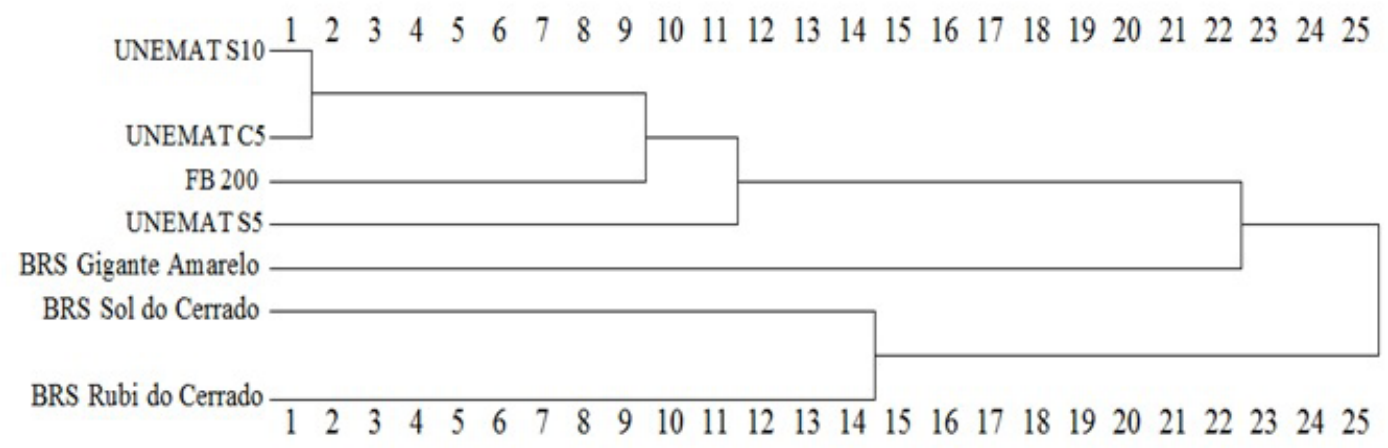

FIGURE 1 - Dendrogram of dissimilarity between four passion fruit cultivars and three passion fruit populations obtained by the UPGMA method, based on the dissimilarity matrix with multicategoric data.

\section{CONCLUSIONS}

The highest productivity and highest number of fruits were verified in BRS Rubi do Cerrado cultivar and in UNEMAT S10 population.

Populations and cultivars presented physicochemical characteristics that meet the quality required for both fresh market and industry.

Based on the genotype distinction assay, it was observed that descriptors were efficient for population differentiation.

UNEMAT S10 population has characteristics that distinguish it from other cultivars and populations evaluated and high agronomic performance; therefore, it can be released as commercial cultivar.

\section{ACKNOWLEDGMENTS}

To FAPEMAT for the financial support to the research project and for granting the master's degree scholarship.

\section{REFERENCES}

ABREU, S. de P.M.; PEIXOTO, J.R.; JUNQUEIRA, N.T.V.; SOUSA, M.A. de F. Características físico-químicas de cinco genótipos de maracujazeiro-azedo cultivados no Distrito Federal. Revista Brasileira de Fruticultura, Jaboticabal, v.31, n.2, p.487-491, 2009.

AOAC - Association of Official Agriculture Chemists. Official methods of analysis of the association of official analytical chemistry. Washington, 1990. p. 910-928.

BALBINO, J.M. de S. Manejo na colheita e pós-colheita do maracujá. In: COSTA, A. de F.S.; COSTA, A.N. (Ed.). Tecnologias para a produção de maracujá. Vitória: INCAPER, 2005. p.153-179.

BORGES, A.L.; CALDAS, R.C.; LIMA, A. de A. Doses e fontes de nitrogênio em fertirrigação no cultivo do maracujá-amarelo. Revista Brasileira de Fruticultura. Jaboticabal, v.28, n.2, p.301-304, 2006. 
BRASIL. Ministério da Integração Nacional. Programa brasileiro para a melhoria dos padrões comerciais e embalagens de horticultura. Disponível em: <www.integracao.gov.br $>$. Acesso em: 11 out. de 2014.

BRUCKNER C. H; PICANÇO M. C. (Ed.). Maracujá: tecnologia de produção, pós-colheita, agroindústria, mercado. Porto Alegre: Cinco Continentes, 2001. 471p.

CASTRO, J.A., NEVES, C.G., DE JESUS, O.N., OLIVEIRA, E.J. Definition of morpho-agronomic descriptors for the characterization of yellow passion fruit. Scientia Horticulturae, Amsterdam, v.145, p.17-22, 2012.

CAVICHIOLI, J.C.; RUGGIERO, C.; VOLPI, C.A. Caracterização físico-química de frutos de maracujazeiro amarelo submetidos à iluminação artificial, irrigação e sombreamento. Revista Brasileira de Fruticultura, Jaboticabal, v. 30, n. 3, p. 649-656, 2008.

CRUZ, C.D. GENES - a software package for analysis in experimental statistics and quantitative genetics. Acta Scientiarum. Maringá, v.35, n.3, p.271-276, 2013.

CRUZ, C.D. Programa genes - diversidade genética. Viçosa: Editora UFV, 2008. 278p.

EMBRAPA- Empresa Brasileira de Pesquisa Agropecuária. Centro Nacional de Pesquisa de Solos. Sistema brasileiro de classificação de solos. Rio de Janeiro, 2006. 306p.

FARIAS, J.F.; SILVA, L.J.B.; ARAÚJO NETO, S.E.; MENDONÇA, V. Qualidade do maracujá-amarelo comercializado em Rio Branco, Acre. Revista Caatinga, Mossoró, v.20, n.3, p196-202, 2007.

FERREIRA, D. F. SISVAR: a computer statistical analysis system. Ciência e Agrotecnologia, Lavras, v.35, n.6, p.1039-1042, 2011.

FOLEGATTI, M.I.S.; MATSUURA, F.C.A.U. Maracujá: pós-colheita. Brasília: Embrapa Informação Tecnológica, 2002. 51p. (Frutas do Brasil, 23).
GONÇALVES, G.M.; VIANA, A.P.; BEZERRA NETO, F.V.; PEREIRA, M.G.; PEREIRA, T.N.S Seleção e herdabilidade na predição de ganhos genéticos em maracujá-amarelo. Pesquisa Agropecuária Brasileira, Brasília, v.42, n.2, p.193198, 2007.

GRECO, S.M.L.; PEIXOTO, J.R.; FERREIRA, L.M. Avaliação física, físico-química e estimativas de parâmetros genéticos de 32 genótipos de maracujazeiro azedo cultivados no distrito federal.

Bioscience Journal, Uberlandia, v.30, n.1, p.360370,2014

IBGE - Instituto Brasileiro de Geografia e Estatística. Banco de dados agregados SIDRA: produção agrícola, 2014. Disponível em: $<\underline{\text { http://www.sidra.ibge.gov.br/bda/tabela/protabl. }}$ asp? $\mathrm{c}=1613 \& \mathrm{z}=\mathrm{t} \& \mathrm{o}=11 \& \mathrm{i}=\mathrm{P}>$. Acesso em: $10 \mathrm{mar}$. de 2016.

KRAUSE, W.; NEVES, L.G.;VIANA,A.P.;ARAÚJO, C.A.T.; FALEIRO, F.G. Produtividade e qualidade de frutos de cultivares de maracujazeiro-amarelo com ou sem polinização artificial. Pesquisa Agropecuária Brasileira. Brasília, DF, v.47, n.12, p.1737-1742, 2012.

MAPA -Ministério da Agricultura Pecuária e Abastecimento. Instruções para execução dos ensaios de distinguibilidade, homogeneidade e estabilidade de cultivares de Passiflora. 2008. Disponível em: <http:/www.agricultura.gov.br $>$. Acesso em: 10 nov. 2014.

MARTINS, J.A.; DALLACORT, R.; INOUE, M.H.; SANTI, A.; KOLLING, E.M.; COLETTI, A.J. Probabilidade de precipitação para a microrregião de Tangará da Serra, Estado do Mato Grosso. Pesquisa Agropecuária Tropical, Goiânia, v.40, n.3, p.291296,2010

MEDEIROS, S.A.F.; YAMANISHI, O.K.; PEIXOTO, J.R.; PIRES, M.C.; JUNQUEIRA, N.T.V.; RIBEIRO, J. G.B.L. Caracterização físicoquímica de progênies de maracujá-roxo e maracujáazedo cultivados no Distrito Federal. Revista Brasileira de Fruticultura, Jaboticabal, v. 31, n. 2, p. 492-499, 2009.

MELETTI, L.M.M. Avanços na cultura do maracujá no Brasil. Revista Brasileira de Fruticultura, Jaboticabal, v.33, n.1, p. 83-91, 2011. 
NASCIMENTO, T.B.; RAMOS, J.D.; MENEZES, J.B. Características físicas do maracujá-amarelo produzido em diferentes épocas. Pesquisa Agropecuária Brasileira, Brasília, DF, v.34, n.12, p.2353-2358, 1999.

NEGREIROS, J.R.S.; ARAÚJO NETO, S.E.; ÁLVARES, V.S.; LIMA, V.A.L.; OLIVEIRA, T.K. Caracterização de frutos de progênies de meiosirmãos de maracujazeiro-amarelo em Rio Branco - Acre. Revista Brasileira de Fruticultura, Jaboticabal, v.30, n.2, p.431-437, 2008.

PIMENTEL, L.D.; SANTOS, C.E.M.; FERREIRA, A.C.C.; MARTINS, A.A.; WAGNER JÚNIOR, A.; BRUCKNER, C.H. Custo de produção e rentabilidade do maracujazeiro no mercado agroindustrial da Zona da Mata Mineira. Revista Brasileira de Fruticultura, Jaboticabal, v.31, n.2, p.397-407, 2009.
SOUSA, L.B.; SILVA, E.M.; GOMES, R.L.F.; LOPES, A.C.A.; SILVA, I.C.V. Caracterização e divergência genética de acessos de passiflora edulis e $p$. cincinnata com base em características físicas e químicas de frutos. Revista Brasileira de Fruticultura, Jaboticabal, v.34, n.3, p.832-839, 2012.

ZACCHEO, P.V.C.; AGUIAR, R.S.; STENZEL, N.M.C.; SERA, T.; NEVES, C.S.V.J. Produção e características qualitativas dos frutos de híbridos de maracujazeiro-amarelo. Revista Brasileira de Fruticultura, Jaboticabal, v.34, n.4, p.1113-1120, 2012. 